\title{
Sistem Pendukung Keputusan Penentuan Bonus Karyawan Menggunakan Metode Weighted Product Pada Toko Mitra Solution
}

\author{
Wanhendra ${ }^{1}$, Yafri $^{2}$, Yogi Aris Pratama ${ }^{3}$ \\ 1,3 Jurusan Teknik Informatika STT Indonesia Tanjungpinang \\ Jln. Pompa Air No. 28 Tanjungpinang Kepulauan Riau Indonesia \\ ${ }^{1}$ wan.itproject@gmail.com \\ 2yafri2301@gmail.com \\ 3yogip0451@gmail.com
}

\begin{abstract}
Intisari - Dalam setiap perusahaan, instansi, organisasi atau badan usaha akan memberikan gaji sebagai kompensasi dari kerja seorang karyawan, disamping pemberian gaji pokok pada karyawannya, setiap instansi seringkali memberikan bonus disamping gaji pokok untuk memacu kinerja dan produktifitas kerja karyawannya dikarenakan seorang karyawan yang menerima bonus tersebut harus memenuhi beberapa kriteria tertentu yang berhubungan dengan kedisiplinan, kinerja, dan produktifitas sesuai yang ditentukan oleh masing-masing instansi atau perusahaan. Bagi setiap usaha yang telah menggunakan sistem informasi berbasis komputer dalam kegiatan usahanya maka memerlukan sistem pendukung keputusan untuk menentukan karyawan manakah yang memiliki prioritas untuk mendapatkan bonus berdasarkan dengan kinerja dan produktifitasnya serta dapat menentukkan besarnya bonus yang pantas untuk diterima karyawan tersebut. Sistem pendukung keputusan ini juga dapat berguna untuk memonitor kinerja karyawan dari waktu ke waktu. Sistem ini juga dapat digunakan sebagai acuan dalam penentuan langkah selanjutnya bagi karyawan yang berprestasi maupun tidak. Dalam penelitian ini akan diangkat sebuah kasus yaitu membuat sebuah aplikasi yang dapat diterapkan dalam penentuan bonus karyawan dengan metode weighted prodiuct yang dibuat dalam satu bentuk sistem informasi berbasis website. Penelitian ini dilakukan dengan metode kualitatif dan pengumpulan data yang dapat membantu dalam membangun aplikasi ini. Kemudian dilakukan pula tinjauan keperluan pengguna dalam proses input dan output. Sehingga didapatlah sebuah sistem yang tidak hanya dapat melakukan penyimpanan data dan perhitungan bonus, namun juga dapat mengedit, menghapus data. Aplikasi ini dibuat dengan bahasa pemrograman PHP dan HTML dengan tools berupa aplikasi visual studio code, MSQL sebagai database serta XAMPP sebagai server untuk menjalankan aplikasi ini.
\end{abstract}

Kata kunci-Weighted Product, Aplikasi, Penentuan Bonus Karyawan, Website.

Abstract - In each company, agencies, organization or business entity will give salary as compensation from work an employee, besides the provision of basic salary its employees, every agency often give a bonus besides basic salary to spur performance and productivity work employees because an employee who receive the bonus had to close some certain criteria concerning their discipline, performance, and productivity according to set by each agencies or company. For any effort who had computer-based information system in their business activities so need the support system the decision to determine employees will that has priority to get a bonus based on with the performance and their productivities are and can menentukkan the size of the bonus deserve to the workers.The support system this decision also could be useful to monitor employee performance from time to time.This system can also be used as a reference in the determination of the next step for employees who performed well or not.In this research will be appointed a case of making an application that can be applied in the determination of a employee with the weighted prodiuct made in one form website based information system. The research is conducted by a method of qualitative and collecting data which can help in building this application.Then also conducted a review the needs of users in the process of input and output.So that found a system that not only can do data storage and calculations, bonus but also can edit, erasing the. This application made by a programming language php and html with tools application Visual Studio Code, MySQL as databases and XAMPP as servers to run this.

Keywords-weighted product, application the determination of bonus, employees . website.

\section{Pendahuluan}

\section{A. Latar Belakang}

Dalam setiap perusahaan, instansi, organisasi atau badan usaha akan memberikan gaji sebagai kompensasi dari kerja seorang karyawan, disamping pemberian gaji pokok pada karyawannya, setiap instansi seringkali memberikan bonus disamping gaji pokok untuk memacu kinerja dan produktifitas kerja karyawannya dikarenakan seorang karyawan yang menerima bonus tersebut harus memenuhi beberapa kriteria tertentu yang berhubungan dengan kedisiplinan, kinerja, dan produktifitas sesuai yang ditentukan oleh masing-masing instansi atau perusahaan.

Bagi setiap usaha yang telah menggunakan sistem informasi berbasis komputer dalam kegiatan usahanya maka memerlukan sistem pendukung keputusan untuk menentukan karyawan manakah yang memiliki prioritas untuk 
mendapatkan bonus berdasarkan dengan kinerja dan produktifitasnya serta dapat menentukkan besarnya bonus yang pantas untuk diterima karyawan tersebut. Sistem pendukung keputusan ini juga dapat berguna untuk memonitor kinerja karyawan dari waktu ke waktu. Sistem ini juga dapat digunakan sebagai acuan dalam penentuan langkah selanjutnya bagi karyawan yang berprestasi maupun tidak.

Bonus merupakan segala sesuatu yang diterima dapat berupa fisik maupun non fisik dan harus dihitung dan diberikan kepada seseorang, sistem bonus yang baik akan mampu memberikan kepuasan bagi karyawan dan memungkinkan toko/perusahaan memperoleh penghasilan yang banyak tiap bulannya.

Pada Toko Mitra Solution terdapat pemberian bonus karyawan, saat ini masih dilakukan secara manual. Dengan mengecek satu persatu kriteria yang dijadikan pedoman dasar dalam pengambilan keputusan berapa banyak jumlah bonus yang akan diberikan kepada karyawan setiap bulannya pencatatan data masih manual dan menghasilkan data fisik berupa buku dan kertas sehingga tingkat keamanan dan kerapiannya pun juga memiliki lebih banyak resiko seperti kerusakan, hilang, dan kesalahan dalam penulisan. Hal ini terjadi karena pihak yang diberi kepercayaan dalam pengambilan keputusan hanya melihat sebagian dari kriteriakriteria yang telah ditentukan. Oleh karena itu dibutuhkan suatu sistem yang dapat membantu pihak toko/perusahaan dalam pengambilan keputusan berdasarkan kriteria tersebut

Metode Weigthted Product adalah metode penyelesaian dengan menggunakan perkalian untuk menghubungkan rating atribut, dimana rating harus dipangkatkan terlebih dahulu dengan bobot atribut yang bersangkutan. Proses ini sama halnya dengan proses normalisasi. Metode Weighted Product (WP) adalah salah satu analisis keputusan multi kriteria (MCDA) yang sangat terkenal atau metode pengambilan keputusan multi kriteria (MCDM). Metode Weighted Product merupakan metode pengambilan keputusan dengan cara perkalian untuk menghubungkan rating atribut, dimana rating setiap atribut harus dipangkatkan dulu dengan bobot atribut yang bersangkutan.

Dengan metode tersebut diharapkan penilaian akan lebih tepat karena didasarkan pada nilai kriteria dan bobot yang sudah ditentukan sehingga akan mendapatkan hasil yang lebih akurat terhadap karyawan yang akan menerima bonus tersebut. Berdasarkan uraian diatas maka penulis akan meneliti masalah dengan judul "SISTEM PENDUKUNG KEPUTUSAN PENENTU BONUS KARYAWAN MENGGUNAKAN METODE WEIGHTED PRODUCT DI TOKO MITRA SOLUTION".

\section{B. Identifikasi Masalah}

Identifikasi masalah adalah suatu tahapan proses merumuskan masalah yang akan diselesaikan. Berdasarkan latar belakang masalah yang telah diuraikan diatas, masalah yang teridentifikasi yaitu :
1. Kesulitan untuk menentukan bonus karyawan berdasarkan kriteria-kriteria yang ada.

2. Kesulitan dalam mencari data kriteria untuk menentukan bonus karyawan.

3. Belum adanya sistem pendukung keputusan penentu bonus karyawan dengan metode weighted product.

C. Tujuan Penelitian

Tujuan penelitian ini merupakan hasil yang hendak dicapai dalam penelitian yang berkontribusi pada ilmu pengetahuan. Dalam bagian ini diuraikan jawaban yang dihubungkan dengan rumusan masalah. Tujuan perancangan sistem pendukung keputusan dalam menenukan bonus karyawan di Toko Mitra Solution terbagi menjadi dua. yakni sebagai berikut:

a. Tujuan Bagi Mahasiswa:

1. Sebagai Menerapkan hasil kemampuan yang diperoleh dari akademik ke dunia kerja yang nyata.

2. Menambah wawasan dan pengetahuan pada penulis dalam menyusun suatu sistem pendukung keputusan dimasa yang akan datang

b. Tujuan Bagian Pengguna:

1. Dapat memperoleh informasi tentang penentuan bonus karyawan menggunakan metode weighted product.

2. Mempermudah dalam menentukan bonus karyawan menggunakan metode weighted product.

D. Kajian Pustaka

\section{Sistem Pendukung Keputusan}

Pengertian Sistem Pendukung Keputusan (SPK) atau Decision Support Systems (DSS) adalah bagian dari sistem informasi berbasis komputer (termasuk sistem berbasis pengetahuan (manajemen pengetahuan)) yang dipakai untuk mendukung pengambilan keputusan dalam suatu organisasi atau perusahaan.

Definisi Sistem Pendukung Keputusan adalah sistem komputer yang mengolah data menjadi informasi untuk mengambil keputusan dari masalah semi terstruktur yang spesifik.

SPK merupakan implementasi teori pengambilan keputusan yang telah diperkenalkan oleh ilmu seperti operation research dan menegement science, hanya bedanya jika dahulu untuk mencari penyelesaian masalah yang dihadapi harus dilakukan perhitungan iterasi secara 
manual (biasanya untuk mencari nilai minimum, maksimum, atau optimum), saat ini computer PC menawarkan kemampuannya untuk menyelesaikan persoalan yang sama dalam waktu relatif singkat.

Sistem Pendukung Keputusan (SPK) pertama kali diungkapkan pada awal tahun 1970-an oleh Michael S. Scott Morton dengan istilah Management Decision System yaitu suatu sistem yang berbasis komputer yang ditunjukan untuk membantu pengambil keputusan dengan memanfaatkan data dan model tertentu untuk memecahkan berbagai persoalan yang tidak terstruktur.

\section{Metode Weighted Product}

Fuzzy Multiple Attribute Decision Making (FMADM) adalah suatu metode yang digunakan untuk mencari alternatif optimal dari sejumlah alternatif dengan kriteria tertentu. Inti dari Fuzzy Multiple Attribute Decision Making (FMADM) adalah menentukan nilai bobot untuk setiap atribut, kemudian dilanjutkan dengan proses perankingan yang akan menyeleksi alternatif yang sudah diberikan. [14]

Pada dasarnya, ada 3 pendekatan untuk mencari nilai bobot atribut, yaitu pendekatan subyektif, pendekatan obyektif dan pendekatan integrasi antara subyektif \& obyektif. Masing-masing pendekatan memiliki kelebihan dan kelemahan. Pada pendekatan subyektif, nilai bobot ditentukan berdasarkan subyektifitas dari para pengambil keputusan, sehingga beberapa faktor dalam proses perankingan alternatif bisa ditentukan secara bebas. Sedangkan pada pendekatan obyektif, nilai bobot dihitung secara matematis sehingga mengabaikan subyektifitas dari pengambil keputusan.

Ada beberapa metode yang dapat digunakan untuk menyelesaikan masalah Fuzzy Multiple Attribute Decision Making (FMADM) antara lain:
a. Simple Additive Weighting Method (SAW)
b. Weighted Product (WP)
c. ELECTRE
d. Technique for Order Preference by Similarity to Ideal Solution (TOPSIS)
e. Analytic Hierarchy Process (AHP)

Metode Weighted Product memerlukan proses normalisasi karena metode ini mengaluhkan hasil penilaian setiap atribut. Hasil perkalian tersebut belum bermakna jika belum dibandingkan (dibagi) dengan nilai standart. Bobot untuk atribut manfaat berfungsi sebagai pangkat positif dalam proses perkalian, sementara bobot biaya berfungsi sebagai pangkat negatif.[16]

Metode WP Merupakan metode pengambilan keputusan dengan cara perkalian untuk menghubungkan rating atribut, dimana rating setiap atribut harus dipangkatkan dulu dengan bobot atribut yang bersangkutan. WP adalah salah satu analisis multikriteria keputusan (multi-criteria decision analysis / MCDA) yang sangat terkenal. Metode multi-kriteria pengambilan keputusan multi-criteriadecision making (MCDM). Metode MCDA, yang diberikan adalah satu set terbatas dari alternatif keputusan yang dijelaskan dalam hal sejumlah kriteria keputusan. Setiap alternatif keputusan dibandingkan dengan yang lain dengan mengalikan sejumlah rasio, satu untuk setiap kriteria keputusan. Setiap rasio diangkat ke kekuasaan setara dengan berat relatif dari kriteria yang sesuai. [15]

Metode Weighted Product menggunakan perkalian untuk menghubungkan rating atribut, dimana rating setiap atribut harus dipangkatkan dulu dengan bobot atribut yang bersangkutan. Langkah-langkah dalam menggunakan metode ini adalah :

a. Menentukan kriteria-kriteria yang akan dijadikan acuan dalam pengambilan keputusan.

b. Menentukan rating kecocokan setiap alternatif pada setiap kriteria.

c. Menentukan bobot preferensi tiap kriteria.

d. Mengalikan seluruh atribut bagi sebuah alternatif dengan bobot sebagai pangkat positif untuk atribut keuntungan dan bobot berpangkat negatif untuk atribut biaya.

Metode Weighted Product menggunakan perkalian untuk menghubungkan rating atribut, dimana rating setiap atribut harus dipangkatkan dulu dengan bobot.[15]

Langkah - langkah dalam perhitungan metode Weighted Product adalah sebagai berikut :

a. Mengalihkan seluruh atribut bagi seluruh alternative dengan bobot sebagai pangkat positif bagi atribut biaya.

b. Hasil perkalian dijumlahkan untuk menghasilkan nilai pada setiap alternative

c. Membagi nilai $\mathrm{V}$ bagi setiap alternatif dengan nilai pada setiap alternative

d. Ditemukan urutan alternatif terbaik yang akan menjadi keputusan.

\section{Website}

Website adalah halaman informasi yang disediakan melalui jalur internet sehingga bisa di akses di mana pun selama terkoneksi dengan jaringan internet. Website merupakan komponen atau kumpulan komponen yang terdiri dari teks, gambar, suara, animasi, sehingga lebih merupakan media informasi yang menarik untuk di kunjungi.

\section{Pemodelan Sistem}

Pada perancangan sebuah sistem diperlukan adanya penerapan konsep permodelan sistem, karena permodelan 
ini menentukan bagaimana suatu sistem akan menyelesaikan apa yang seharusnya diselesaikan oleh sistem itu sendiri. Inti dari analisis dan konsep permodelan sistem ini adalah untuk berusaha melihat keseluruhan masalah dalam hubungannya dengan cara sistematis, menyelidiki tujuan sistem dan kriteria untuk keberhasilan sistem tersebut serta untuk menilai alternatif-alternatif yang dipandang dari sudut keberhasilan dan biaya. Analisis sistem informasi adalah penguraian suatu sistem yang utuh kedalam bagian-bagian komponennya dengan maksud untuk mendefenisikan dan mengevaluasi permasalahan-permasalahan, kesempatan-kesempatan, hambatan- hambatan yang diharapkan. Dalam permodelan sistem konsep aplikasi ini berdasarkan orientasi program dan orientasi data. Dalam tradisional file manajemen berdasarkan orientasi program, susunan dari file data distribusi pada penyimpanan dan organisasi file dipilih sedemikian rupa sehingga aplikasi dapat digunakan secara optimal.[7]

Untuk membangun sistem informasi yang besar dan kompleks, diperlukannya membuat model guna menggambarkan dan mengkomunikasikan secara sederhana rancangan sistem yang dibuatnya kepada pengelola perusahaan, agar sistem dapat dipahami dan dikoreksi. Melalui pemodelan, akan digambarkan aliran data yang akan diproses menjadi informasi dan aliran distribusinya secara sederhana, sehingga arus data dan informasi dapat terlihat secara jelas. Penggambaran pemodelan dapat menggunakan sistem flowchart atau blok diagram. Melalui penggambaran, dapat dilakukan efisiensi aliran data dan informasi sehingga sistem menjadi efisien., yaitu:

a. Flowmap adalah campuran peta dan flowchart, yang menunjukkan pergerakan benda dari satu lokasi ke lokasi lain, flowmap diagram disebut juga diagram alir dokumen yaitu skema atau diagram yang menggambarkan aliran dokumen yang terjadi dalam sistem maupun entitas-entitas yang berada di luar sistem. Proses yang digambarkan dalam diagram ini tidak hanya proses yang dikerjakan secara komputerisasi, tetapi proses manual juga bisa ditampilkan sehingga flowmap diagram ini bisa menggambarkan prosedur ataupun kejadian yang terjadi dalam sistem yang dibuat secara lengkap.[14]

b. Diagram konteks adalah diagram yang berada pada level yang paling tinggi yaitu level 0 (nol) yang menggambarkan ruang lingkup sistem yang global. Setiap sistem dibatasi boundary, diagram arus data menggambarkan jaringan masukan dan keluaran dari sistem, level ini hanya ada satu proses dan tidak ada data store.

c. Data Flow Diagram adalah sebuah teknik grafis yang menggambarkan aliran informasi dan transformasi yang diaplikasikan pada saat data bergerak dari input menjadi output . DFD merupakan alat perancangan sistem yang berorientasi pada alur data dan dapat digunakan untuk penggambaran analisa maupun rancangan sistem.[8]

\section{Perangkat Lunak Yang Digunakan}

Perangkat lunak (software) yang penulis gunakan dalam membuat aplikasi ini adalah sebagai berikut:

a. PHP (Hypertext Preprocessor) adalah bahasa pemrograman script server side yang didesain untuk pengembangan web. Disebut bahasa pemrograman server side karena PHP diproses pada komputer server. Hal ini berbeda dibandingkan dengan bahasa pemrograman client side seperti JavaScript yang diproses pada web browser (client). PHP dapat digunakan dengan gratis dan bersifat Open Source. PHP dirilis dalam lisensi PHP License, sedikit berbeda dengan lisensi GNU General Public License (GPL) yang bisa digunakan untuk proyek Open Source.

b. MySQL merupakan perangkat lunak yang juga bersifat open source. Sesuai namanya, bahasa standar yang digunakan adalah SQL. SQL singkatan dari Structure Query Language, yang merupakan bahasa standar untuk pengolahan database. MySQL bekerja menggunakan bahasa basis data atau yang sering kita dengar dengan sebutan DBMS (Database Management System).[18]

c. Xampp adalah sebuah paket kumpulan software yang terdiri dari Apache, MySQL, PhpMyAdmin, PHP, Perl, Felezilla dan lain-lain. Xampp berfungsi untuk memudahkan instalasi lingkungan PHP, di mana biasanya lingkungan pembangunan web memerlukan PHP, Apache, MySQL dan PhpMyAdmin serta software yang terkait dengan pengembangan web.

d. Visual Studio Code adalah editor kode sumber yang dikembangkan oleh Microsoft untuk Windows, Linux dan macOS . Ini termasuk dukungan untuk debugging, kontrol Git yang tertanam dan GitHub, penyorotan sintaksis, penyelesaian kode cerdas, snippet, dan refactoring kode. Ini sangat dapat disesuaikan, memungkinkan pengguna untuk mengubah tema, pintasan keyboard, preferensi, dan menginstal ekstensi yang menambah fungsionalitas tambahan. Kode sumber adalah sumber bebas dan terbuka dan dirilis di bawah Lisensi MIT yang permisif. Binari yang dikompilasi adalah freeware dan gratis untuk penggunaan pribadi atau komersial.[12]

\section{Metodologi Penelitian}

Metode penelitian rupakan suatu teknik atau cara untuk mengumpulkan data atau fakta yang nantinya akan dipelajari dan akhirnya sebagai bahan untuk di analisa serta digunakan untuk memudahkan pencarian dan pemecahan suatu masalah. Metode penelitian yang digunakan terbagi menjadi 2 yaitu 
metode pengumpulan data dan metode pengembangan perangkat lunak yang dapat dilihat pada sub bab dibawah ini:

\section{A. Metode Pengumpulan Data}

Dalam kegiatan untuk memperoleh data pada penelitian tugas akhir ini, penulis menggunakan teknik pengumpulan data yang digunakan adalah sebagai berikut :

\section{Observasi}

Melakukan observasi atau peninjauan tempat sebelum pelaksanaan kegiatan pengumpulan data dengan mengadakan pengenalan terhadap objekobjek penelitian, aktivitas kerja dan bahan kajian pada lembaga bimbingan belajar dSsc. Salman Bandung Kota Tanjungpinang.

2. Wawancara

Melakukan wawancara secara langsung dengan pihak-pihak yang terlibat dalam sistem pendaftaran dan akademik dSsc Salman Bandung.

3. Studi Kepustakaan

Melakukan pengumpulan data secara tidak langsung dengan melakukan studi kepustakaan, yaitu dengan mengumpulkan data-data dan teori-teori yang berhubungan dengan penulisan ini.

\section{B. Metode Pengenbangan Perangkat Lunak}

Metode pengembangan perangkat lunak yang digunakan dalam membangun website informasi ini menggunakan model Waterfall yang menyarankan pengembangan perangkat lunak secara sistematik dan berurutan yang dimulai dari tingkatan sistem tertinggi dan berlanjut ke tahap analisa, desain, pengkodean, pengujian dan pemeliharaan. [9]

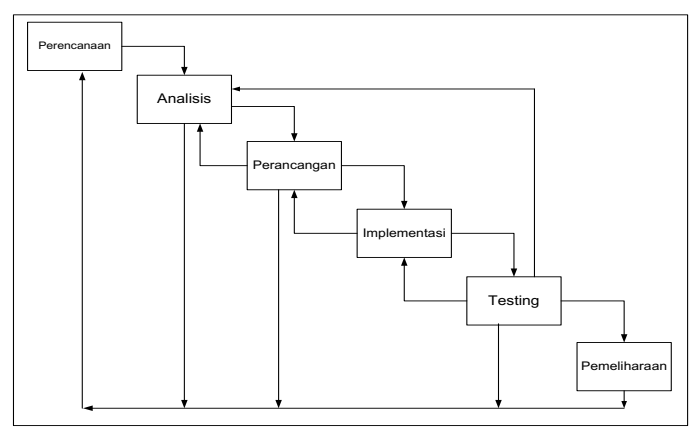

Gambar 1. Model Waterfall [9]

Keterangan :

1. Perencanaan (Engineering System) adalah Tahapan mengenai masalah perangkat lunak, perangkat keras dan sumber daya manusia.

2. Analisis (Analysis) adalah Melakukan analisis sistem dengan mencari penyebab-penyebab masalah yang timbul sabagai dasar perancangan sistem baru.

3. Perancangan (Design) adalah Proses mengubah kebutuhan-kebutuhan menjadi bentuk karakteristik yang dimulai dengan penulisan program design tadi harus diubah menjadi bentuk yang dimengerti sistem.
4. Implementasi (Implementation) adalah Tahap penerjemahan desain kedalam bahasa pemrograman yang sesuai dengan kebutuhan.

5. Pengkodean (Coding) adalah desain yang harus diubah bentuknya menjadi bentuk yang dimengerti oleh komputer. Tahanpan ini yang secara teknik akan dikerjakan oleh sistem.

6. Pengujian (Testing) adalah Tahap pengujian perangkat lunak yang telah dikembangkan untuk cover kesalahan-kesalahan dan menjamin bahwa mesukan sesuia dengan hasil yang ditentukan.

7. Pemeliharaan (Maintenance) adalah Tahap perawatan sistem yang telah dikembangkan seperti perawatan perangkat lunak, perangkat keras dan media lain yang berhubungan dengan komputer. Pada tahap ini segala kemungkinan mengenai kekurangan perangkat lunak baik berupa kesalahan atau hal-hal yang ditambahkan kedalam perangkat lunak.

\section{HASIL DAN PEMBAHASAN}

\section{A. Perancangan Sistem}

Perancangan adalah proses selanjutnya setelah proses analisis. Di dalam proses ini, sistem yang telah dianalisis kemudian dituangkan dalam bentuk konsep untuk menjadi pondasi pengembangan sistem selanjutnya, yaitu proses implementasi dan pengkodean (coding).

1. Analisis Sistem Input Data Karyawan yang Diusulkan Dibawah ini adalah usulan proses input data karyawan yaitu sebagai berikut:

a. Admin melakukan input data karyawan kedalam sistem dan terhubung langsung pada tabel karyawan.

b. Kemudian, sistem menampilkan laporan data karyawan. Admin melakukan cetak data karyawan dan memberikan data karyawan tersebut kepada pimpinan.

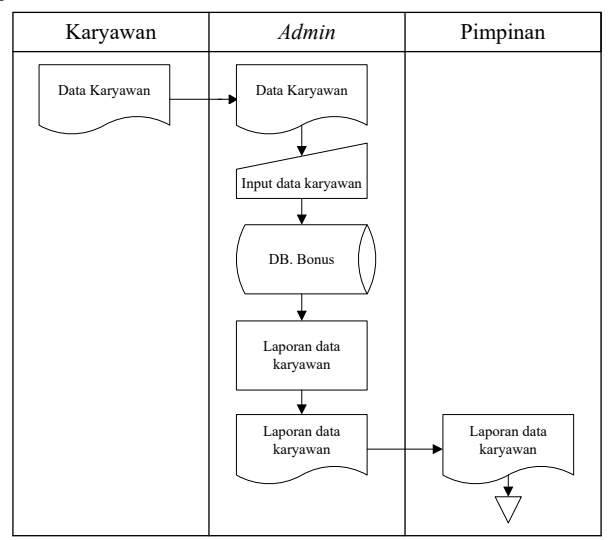

Gambar 2. Flowmap Input Data Karyawan yang Diusulkan

2. Analisis Sistem Input Nilai Indikator yang Diusulkan

Dibawah ini adalah usulan proses input nilai indicator yang diusulkan yaitu sebagai berikut : 
a. Admin melakukan input NIK karyawan untuk melakukan input nilai indicator.

b. Sistem aplikasi memproses pencarian NIK dan menampilkan data.

c. Admin memeriksa data yang di tampilkan sesuai atau tidak. Jika, sudah sesuai Admin melakukan input nilai indicator.

d. Sistem memproses hitung nilai indicator.

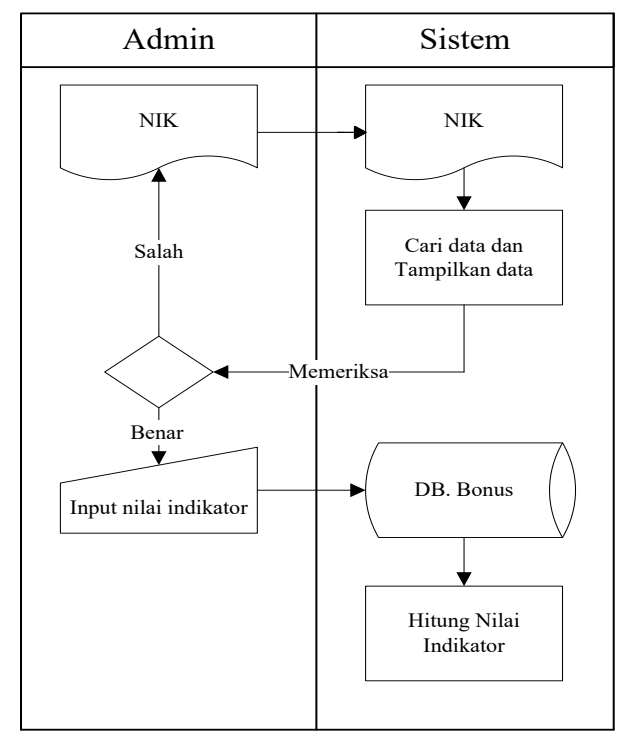

Gambar 3. Flowmap Input Nilai Indikator yang Diusulkan

3. Analisis Sistem Penentuan Bonus Karyawan yang Diusulkan

Dibawah ini adalah usulan proses penentuan bonus karyawan yaitu sebagai berikut :

a. Admin melakukan input NIK karyawan.

b. Sitem memproses pencarian data NIK dan menampilkan data. Kemudian, sistem memproses perhitungan bonus karyawan.

c. Kemudian sistem aplikasi menampilkan data-data bonus karyawan dan memproses cetak bonus karyawan.

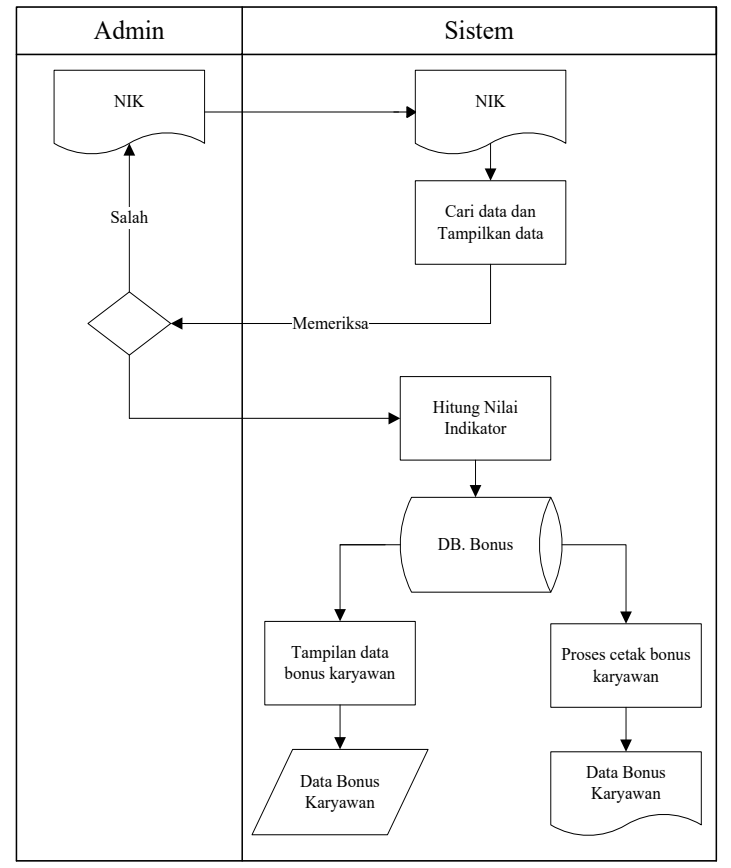

Gambar 4. Flowmap Sistem Penentuan Bonus yang Diusulkan

\section{B. Perancangan Struktur File}

Dalam pembuatan aplikasi ini dibutuhkan suatu spesifikasi file untuk mempermudah dalam melakukan kegiatan pemrograman, yang dapat dilihat dari tabel-tabel berikut ini:

TABEL I

KARYAWAN

\begin{tabular}{|c|c|c|c|c|}
\hline No. & $\begin{array}{c}\text { Nama } \\
\text { Kolom }\end{array}$ & Tipe & Ukuran & Keterangan \\
\hline 1 & nik & int & 11 & $\begin{array}{l}\text { Nomor Induk } \\
\text { Karyawan }\end{array}$ \\
\hline 2 & nama & varchar & 255 & $\begin{array}{l}\text { Nama } \\
\text { Karyawan }\end{array}$ \\
\hline 3 & jabatan & varchar & 225 & $\begin{array}{l}\text { Jabatan } \\
\text { Karyawan }\end{array}$ \\
\hline 4 & Tgl_lahir & date & - & $\begin{array}{l}\text { Tanggal Lahir } \\
\text { Karyawan }\end{array}$ \\
\hline 5 & $\mathrm{Jk}$ & varchar & 225 & $\begin{array}{l}\text { Jenis Kelamin } \\
\text { Karyawan }\end{array}$ \\
\hline 6 & Status2 & varchar & 225 & $\begin{array}{l}\text { Status } \\
\text { Karyawan }\end{array}$ \\
\hline 7 & agama & varchar & 50 & $\begin{array}{l}\text { Agama } \\
\text { Karyawan }\end{array}$ \\
\hline 8 & Alamat & varchar & 225 & $\begin{array}{l}\text { Alamat } \\
\text { Karyawan }\end{array}$ \\
\hline 9 & telp & varchar & 20 & $\begin{array}{l}\text { Telephone } \\
\text { Karyawan }\end{array}$ \\
\hline 10 & email & varchar & 100 & $\begin{array}{l}\text { Email } \\
\text { Karyawan }\end{array}$ \\
\hline
\end{tabular}




\begin{tabular}{|c|c|c|c|c|}
\hline & \multicolumn{4}{|c|}{$\begin{array}{l}\text { TABEL II } \\
\text { BONUS }\end{array}$} \\
\hline No. & $\begin{array}{l}\text { Nama } \\
\text { Kolom }\end{array}$ & Tipe & Ukuran & Keterangan \\
\hline 1 & nik & int & 11 & $\begin{array}{l}\text { Nomor Induk } \\
\text { Karyawan }\end{array}$ \\
\hline 2 & nama & varchar & 225 & $\begin{array}{l}\text { Nama } \\
\text { Karyawan }\end{array}$ \\
\hline 3 & jabatan & varchar & 225 & $\begin{array}{l}\text { Jabatan } \\
\text { Karyawan }\end{array}$ \\
\hline 4 & $\mathrm{c} 1$ & int & 11 & Nilai Indikator \\
\hline 5 & c2 & int & 11 & Nilai Indikator \\
\hline 6 & c3 & int & 11 & Nilai Indikator \\
\hline 7 & c4 & int & 11 & Nilai Indikator \\
\hline 8 & c5 & int & 11 & Nilai Indikator \\
\hline 9 & $\mathrm{~s}$ & float & - & Matriks S \\
\hline 10 & $\mathrm{v}$ & float & - & Matriks V \\
\hline 11 & ranking & varchar & 225 & $\begin{array}{l}\text { Hasil } \\
\text { Perhitungan }\end{array}$ \\
\hline
\end{tabular}

\section{Perancangan Struktur Menu}

Struktur menu merupakan bentuk umum dalam suatu perancangan aplikasi yang dapat memudahkan pengguna dalam menggunakan aplikasi yang di bangun. Adapun struktur menu yang akan di implementasikan dalam apikasi ini adalah seperti gambar di bawah ini:

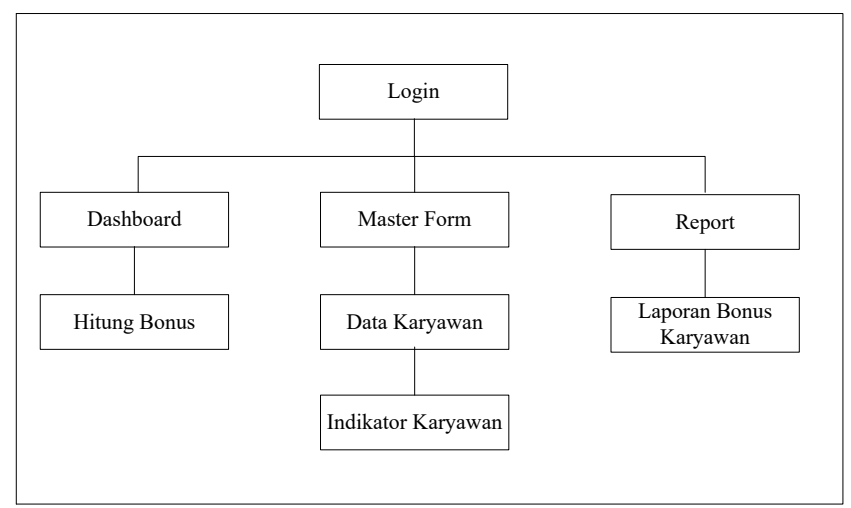

Gambar 5. Struktur Program

D. Implementasi

Implementasi antar muka merupakan tampilan aplikasi yang berfungsi sebagai antar muka masukan data ke dalam database atau output dari database. Tampilan antar muka dapat dilihat pada gambar-gambar sebagai berikut:antar muka masukan data ke dalam database atau output dari database.
Gambar 6 adalah tampilan halaman Dashboard pertama kali masuk website

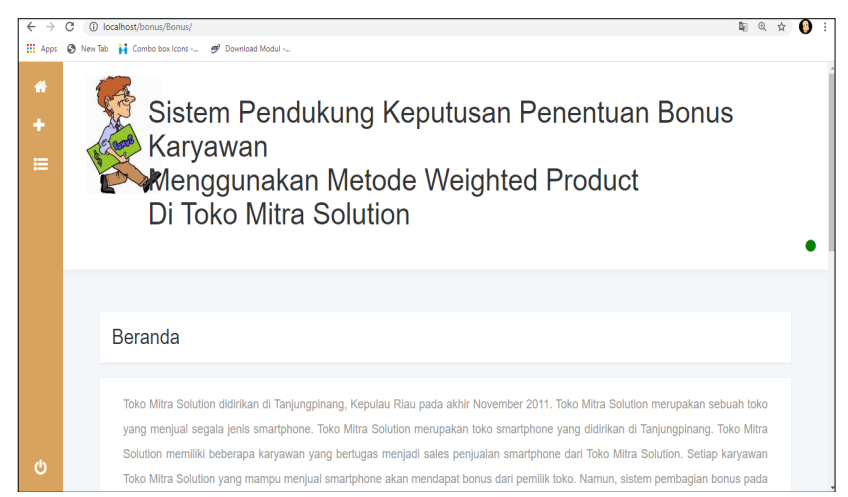

Gambar 6. Halaman Dashboard

Gambar 7 adalah tampilan halaman form Input data karyawan digunakan sebagai interface admin untuk memasukkan data karyawan

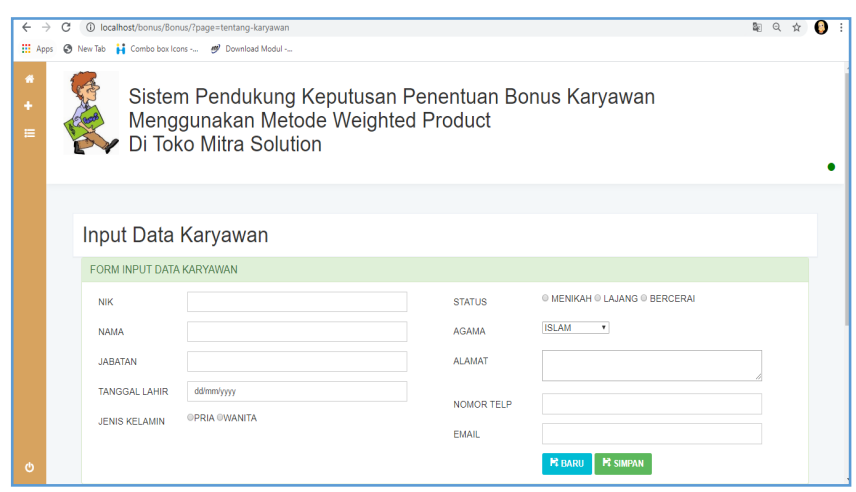

Gambar 7. form Input Data Karyawan

Gambar 8 adalah tampilan halaman form Input Indikator yang digunakan sebagai interface admin untuk memasukkan data Indikator Karyawan.

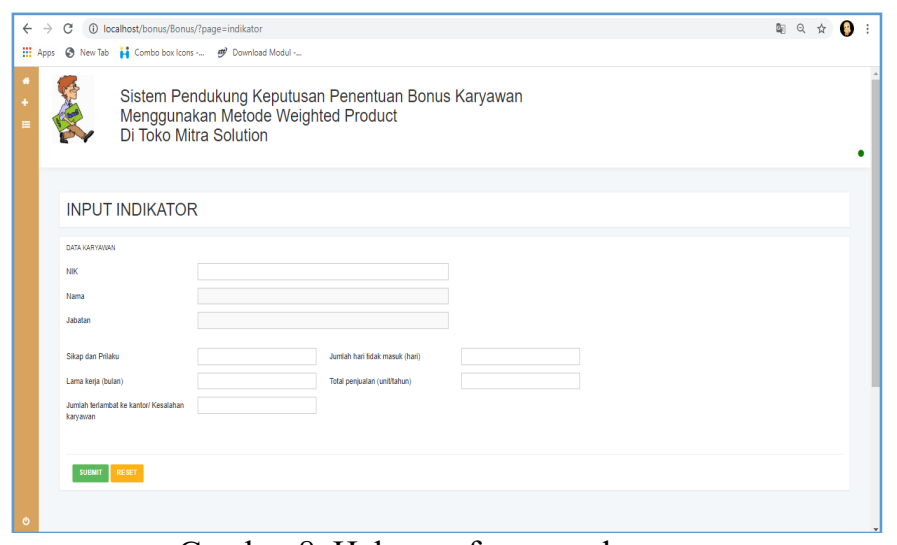

Gambar 8. Halaman form pembayaran

Gambar 9 adalah tampilan halaman form Hitung Bonus yang digunakan sebagai interface admin untuk memasukkan data Penentuan Bonus Karyawan. 


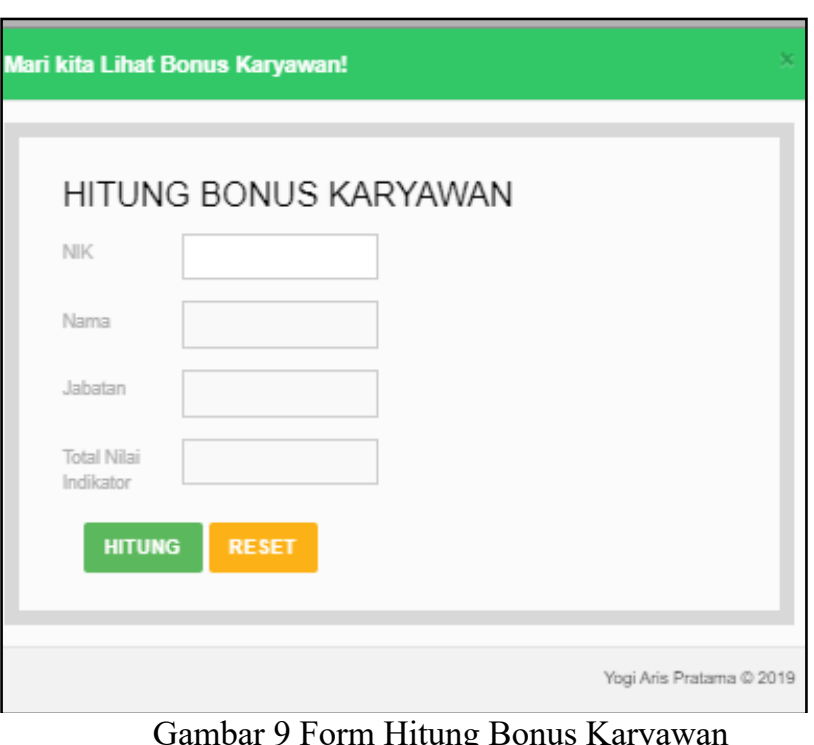

Gambar 9 Form Hitung Bonus Karyawan

Gambar 10 adalah tampilan halaman Laporan Data Bonus Karyawan yang digunakan sebagai interface admin untuk mencetak laporan.

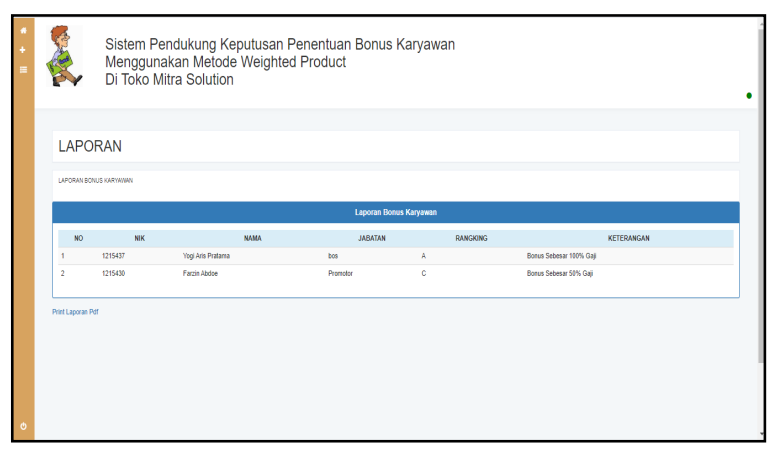

Gambar 10 Form Laporan Data Bonus Karyawan

\section{KESIMPULAN}

Berdasarkan hasil proses perancangan dan implementasi perangkat lunak yang dilakukan kepada sistem, dapat disimpulkan bahwa, dengan adanya sistem ini proses penentuan bonus untuk karyawan di Toko Mitra Solution pemanggilan kembali data (data recall) menjadi lebih mudah dan cepat sehingga tidak ada lagi kesulitan dalam mencari data kriteria untuk menentukan bonus karyawan, selanjutnya dengan adanya sistem ini kesulitan untuk menentukan bonus karyawan berdasarkan kriteria-kriteria yang ada dapat di perkecil dan memudahkan pimpinan dalam pengambilan keputusan lalu kelebihan sistem ini adalah membantu perhitungan dan pengambilan keputusan penentu bonus karyawan dengan metode weighted product dalam proses penentuan bonus untuk karyawan di Toko Mitra Solution ini.

\section{UCAPAN TERIMA KASIH}

Didalam pengerjaan laporan ini, penulis telah melibatkan banyak pihak yang sangat membantu dalam banyak hal. Oleh sebab itu, disini penulis sampaikan rasa terima kasih sedalamdalamnya kepada :

1. Bapak Danandjaya Saputra, M.Kom Selaku dosen pembimbing dalam penyusunan laporan ini.

2. Dosen - dosen Sekolah Tinggi Teknologi Indonesia Tanjungpinang.

3. Orang tua tercinta yang telah banyak memberikan doa dan dukungan kepada penulis secara moril maupun materil hingga laporan ini dapat selesai.

4. Semua pihak yang telah banyak membantu penulis selama penyusunan laporan ini yang tidak dapat penulis sebutkan satu persatu.

\section{REFERENSI}

[1] Hanif Al Fatta, analisis \& perancangan sistem informasi, [Andi offset, 2014], Yogyakarta], hal : 9

[2] HM Jogiyanto, Analisis dan Desain Sistem Informasi, Andi, 2005, Yogyakarta..

[3] Husen Abrar, Rekayasa Perangkat Lunak, Andi, 2014, Yogyakarta.

[4] Kadir Abdul, Pengenalan Teknologi Informasi, Andi, 2003, Yogyakarta.

[5] Prof.Dr.Jogiyanto, HM. MBA. Akt, Analisis dan Desain,[Andi.Yogyakarta], hal.8

[6] Prof. Dr. Mr. S. Prajudi Atmosudirdjo, Analisis dan Perancangan Sistem Informasi, Yogyakarta, 2013, hal 9

[7] Roger S. Pressman, Ph.D, Rekayasa Perangkat Lunak, [Yogyakarta, 2007, Andi], hal.364

[8] Nugroho, Adi, 2005, Analisis dan Perancangan Sistem Informasi dengan Metodologi Berorientasi Objek, Informatika Bandung.

[9] Yakub, Pengantar Sistem Informasi, Graha Ilmu, 2014, Yograkarta

[10] http://andriyani1997.blogspot.com/2017/05/konsep-dasar-sisteminformasi-dan.html. (03/04/19/15:05).

[11] https://www.ilmupengetahuan.co.id/umum/Visual_Studio_Code\&hl=id $\& \mathrm{sl}=$ en\&tl=id\&client $=$ srp. $(03 / 08 / 19 / 22: 17)$

[12] https://jupriyadi.wordpress.com/2011/12/05/sistem-basis-data-entityrelationship-diagram-erd/. (03/04/19 / 18:30).

[13] http://aepnurulhidayat.wordpress.com/2015/08/20pengertian-flowmapby-aep-nurul-hidayah/ (diakses pada 05 Nov 2020 pukul 11.47 WIB)

[14] https://media.neliti.com/media/publications/224919-metode-fuzzymultiple-attribute-decision-15941957.pdf (diakses pada 23 Des 2019 pukul 13.05 WIB)

[15] https://media.neliti.com/media/publications/104175-ID-implementasimetode-weighted-product-unt.pdf (diakses pada 23 Des 2019 pukul 14.12 WIB)

[16] http://riset.potensiutama.ac.id/upload/penelitian/penerbitan jurnal/177182\%20SISTEM\%20PENDUKUNG\%20KEPUTUSAN\%20PENILAI AN\%20KINERJA \%20DOSEN\%20MENGGUNAKAN\%20METODE \%20WEIGHTED\%20PRODUCT.pdf (diakses pada 23 Des 2019 pukul 13.25 WIB)

[17] https://www.niagahoster.co.id/blog/mysql-adalah/ [diakses pada 24 Des 2019 19.12] 